JELTL (Journal of English Language Teaching and Linguistics) e-ISSN: 2502-6062, p-ISSN: 2503-1848

2019, Vol. 4(1)

www.jeltl.org

\title{
Intercultural Communicative Competence (ICC): What Should Indonesian EFL Teachers Have Related to ICC's Elements?
}

\author{
Mas Muhammad Idris \\ Universitas Negeri Yogyakarta, Indonesia \\ masmuhamadidris@gmail.com \\ Agus Widyantoro \\ Universitas Negeri Yogyakarta, Indonesia \\ agus_wiwied@yahoo.com
}

\begin{abstract}
In the twenty-first century life, the demand to become an intercultural speaker becomes very crucial. It is seen through the incremental important attention of having an intercultural communicative competence (ICC) which is seen as one of the main key competencies in global world-wide. This condition urges any teacher to master the ICC completely as to assist their students to become intercultural speakers in multicultural situations. However, this competence has not been noticed thoroughly by Indonesian EFL teachers since most of them are reluctant to develop their competence in term of integrating the elements of ICC into their teaching-learning process. Hence, this present article recommends a number of competencies related to ICC's elements in which the Indonesian EFL teachers should have, namely, the linguistic, sociolinguistic, discourse, and intercultural competence which are considered able to aid the Indonesian EFL teachers in enhancing the students' ICC.

Keywords: Intercultural Speaker, Intercultural Communicative Competence, Indonesian EFL Teachers
\end{abstract}


Mas Muhammad Idris \& Agus Widyantoro

\section{INTRODUCTION}

Today, English is not solely to be one of the world languages due to its hegemony via the world-wide but it is noticed as a lingua franca, a world language, as well. A scholar, Jenkins (2009) argues, the term of English as a lingua franca refers to "specific communication context" which is commonly chosen by a plenty of speakers around the world who come from a diverse lingua-cultural backgrounds. Furthermore, she emphasizes that in the real practice, English is frequently used by amongst non-native English speakers who exist in broader numbers than the native English speakers in narrower ones (p. 200-201). In Indonesia, the English, as a lingua franca, nowadays is needed as a great consideration to be put into the teaching learning process by educators or teachers (Insani, 2018).

In the field of foreign language education, English is defined as an intercultural subject matter in which it is used within particular cultural contexts (Sercu et al., 2004) so that in learning English, it involves "more than the acquisition of linguistic and communicative competence in that language" (p.85-86). In addition, it requires the enhancement in students' familiarity within the language's cultural background and the enhancement of the students' cultural awareness and intercultural competence as well.

Hereinafter, the demand to become an intercultural speaker becomes also pivotal due to its role as one of the key crucial elements in the twenty-first-century life to face and live in global world-wide (Delor, 1996; Sudhoff, 2010; UNESCO, 2006). Other scholars, pertinent to this, Chen $\&$ Starosta (1996) standpoint that there are five essential factors that have changed the world-wide into a global village for the last twentieth century, including (1) the technology development, (2) the globalization of the economy, (3) the development of multiculturalism, (4) the widespread population migrations, and (5) de-emphasis on the Nation-State, has forced the individuals who live in this era to learn, behold, and respect to other people's cultures from their own. Further, the process of globalization has led the important economic and social changes rapidly so that the societies and cultures become interconnected through a number of ways such as transportation, trade, and communication (Rajic \& Rajic, 2015).

However, for the above two latter factors are still based on the United State context while for the three former ones are common issues that can be correlated to any other countries in which Indonesia is no exception. The impact of these indicators make individuals be inter-correlated to each other and urge them to have the intercultural competence in order to live as meaningful and productive as possible in today's world. As a consequence, Sercu (2004) noticed that teachers need to have important roles to assist and prepare their students to be ready in living in a multicultural world. Similarly, some experts (Byram, 1997; Chen \& Starosta, 1999; Deardorff, 2009; Fantini, 2000; Lazar et al, 2007), state that due to the development of IC toward the EFL students, it has been recognized as one of the final aims in English language learning which attempts to provide them much knowledge about cultural diversity, and to assist them to be aware of their own culture as well as respect to others.

Additionally, according to Samovar, Porter, \& McDaniel (2012), the English language education also needs to prepare the students with the competency of intercultural communication as well as the implementation of it in an effective strategy, so that they can portray the cultural dissimilarities and reach more harmonious as well as productive interconnections. Thus, in order to cope and achieve the above condition, especially for developing students' intercultural 
competence, teaching culture should be also taught in advance as a basis and part of the English language learning which has become one of the objectives in the language learning curriculum (Cubukcu, 2013).

Within the Indonesian context, according to Madya (2013), she argues that Indonesian students have naturally and nationally involved in the activity of intercultural language learning due to the condition of multiculturalism that Indonesia has. The fact can be seen through the total of 350 ethnics and 746 languages. Therefore, it is very crucial for the Indonesian students to have knowledge of intercultural competence through intercultural language learning in order to avoid misunderstanding between interlocutors as well as to achieve mutual understanding amongst them that can support the unity of nations. Hence, it is demanded to design an integrated intercultural language learning which indicates that language and culture have a reciprocal relationship.

Also, the impact of rising of globalization in this century enacts the teachers to have an impetus to develop their competence as well as to teach culturally diverse students (CochranSmith, 2005; Darling-Hammond, 2006). However, after conducting preliminary research related to this, it is in contrast with many Indonesian EFL teachers in which they are reluctant to develop their intercultural competence in term of integrating the important components of intercultural communicative competence (ICC), namely the linguistic competence, sociolinguistic competence, discourse competence, and intercultural competence (attitude, knowledge, skill) into their teaching and learning process. The present situation thus should be taken seriously into a consideration for the teachers to assist the students in developing the intercultural competence.

\section{THE NATURE OF COMMUNICATIVE COMPETENCE (CC) TO INTERCULTURAL COMMUNICATIVE COMPETENCE (ICC)}

Starting with the concept of communicative competence (CC) that has been coined by one of the linguists, Hymes who criticized Chomsky's theory related to the acquiring of the first language, argued that to attain the first language acquisition was not merely enough through the grammatical competence but needed to input the aspect of sociolinguistic competence, the ability to use language appropriately. This concept underlay to the development of communicative language teaching (CLT) (Byram, 1997).

However, this concept had been also criticized by Byram (1997) pertaining to Hymes' description of the first language acquisition and communication that it was still based on amongst native speaker context. Yet, in this sense, Hymes emphasized that there is a relationship between the linguistic and sociocultural competencies since he highlights the possibility of the linguistic and cultural spheres that are likely to be interacted (Hymes, 1972).

This however implicitly indicated that the foreign language students have to be able to model themselves as native speakers in acquiring the first language, disregarding the cultural competence and social identities of the students in sort of cultural situations. The concept of communicative competence lies in two things: the effectiveness and appropriateness (Chen \& Starosta, 1996). They further explain for the former as the capacity of an individual to create an intended effect by interacting with the environment. The present capability, however, is considered either as a basic human skill which is attained throughout the learning and socialization process (Weinstein, 1969; White, 1959).

While for the latter, the appropriateness in communication process, Wiemann \& Backlund (1980) as cited in (Chen \& Starosta, 1996) argue that there are three kinds of ability which are 
explored by others too. The first is the ability to know that context may bind the communication so that one can interact appropriately with the combination of social and capabilities of knowledge (Lee, 1979; Trenholm \& Rose, 1981). Secondly, it is the potential to keep away from the responses inappropriately. In this context, the term of response which is considered inappropriate is described as an individual who is unnecessarily intense, abrasive, or bizarre which is probably resulting in negative consequences that could have been turned aside, without sacrificing the goal through a plenty of appropriate actions (Getter \& Nowinski, 1981). Lastly, it is the ability to satisfy appropriately in such communications through sharing feelings, controlling, informing, ritualizing, and imagining (Allen \& Wood, 1978). To sum up, communicative competence is the ability to use and produce the language as a means of communication effectively and appropriately through interaction, and also notice as well as understand the content and context of the encounter so that they can avoid inappropriate response by not violating the norms and also rules of their own till they reach a harmonious conversation.

The term intercultural communicative competence has been widely treated in the literature as the same as communicative competence in general ways (Chen \& Starosta, 1996). Yet, many interculturalists place more emphasis on the definition of intercultural communicative competence based on contextual factors as well as some intended purposes (Byram, 1997; Deardoff, 2006; Fantini, 2009; and Spitzberg \& Cupach, 1984). It is also noticed that each interculturalist has his or her own way to label the "term" such as intercultural communicative competence (ICC) (e.g., Byram, 1997; Deardorff, 2009), intercultural competence (IC) (e.g., Fantini, 2001; Sercu et al, 2005), intercultural communication competence(ICC) (e.g., Chen \& Starosta, 1996), and so forth. From all of these, the term of "intercultural communicative competence" is the most common nomenclature used by scholars, educators, and others to be involved in increasing the ground too (Fantini, 2009).

In the educational context, Byram's definition is mostly used to define what it is called intercultural communicative competence (ICC) as one that is able to communicate with other people from dissimilar countries and cultures in a foreign language (1997). This definition looks simple but rather difficult to understand since it needs more explanations. The three competencies proposed by Byram should be included in terms of linguistic, sociolinguistic, and discourse competence which can be a basic in gaining the new insight of languages and cultures through communicating and negotiating as well as the ability in using the language properly within any cultural situations. Consequently, to reach the label of intercultural speaker, he or she must have those complexities and abilities to deal with a broader range of different situations.

It is quite nice to see from the perspective of the professional domain related to the definition of intercultural communication competence since the term of intercultural competence always implies communicative competence (Sercu, 2010). Chen \& Starosta's definition pertinent to intercultural communication competence is that they emphasize to one who will be a competent person should be able to understand not only how to communicate efficaciously and properly with different people in a specific environment but also how to actualize their own intended purposes in term of communication by respecting and giving positive attitudes towards the people who have multicultural identities (1996: 359). Moreover, another interesting definition may come from Lazer; Kriegler; Lussier; Matei \& Peck (2007) that describe the intercultural communicative competence as the capability to communicate in numerous situations identified as the cross- 
cultural condition effectively and to relate in different contexts identified as the cultural situation appropriately which is employed as an instruction for the language teachers. To further understand pertaining to this definition, it emphasizes two important components: skills, focuses on the development of observing, interpreting, and relating as well as mediating and discovering; and attitudes, focuses on giving empathy, respect, and tolerance for ambiguity, raise interest in, curiosity, openness, as well as promote a sense of willingness to avoid negative judgment (ibid: 9-10).

From the aforementioned definitions, it can be inferred that ICC is the capability of an individual to interact as properly and eloquently as possible through a particular language other than the individual's native language with other people from distinctive linguistic and cultural background. In a nutshell, the language competence consisting of linguistic, sociolinguistic, and discourse competence accompanied by the intercultural competence consisting of attitudes, knowledge, skills, and awareness are considered able in assisting any individuals to successfully and effectively integrate within a particular society with a multicultural background (Tran, 2015).

\section{THE ELEMENTS OF ICC IN WHICH THE INDONESIAN EFL SHOULD HAVE}

Within the area of foreign language education, Byram's model (1997) is recognized as the most influential framework to enhance and assess the students' ICC in various circumstances. In the present model, he divided the language competencies into four parts, which are linguistic competence, sociolinguistic competence, discourse competence, and intercultural competence which comprises five components namely attitude, knowledge, skill of interpretation and relation, skill of discovery and interaction, as well as critical cultural awareness/political education. In accordance with this model, he emphasizes to certain educational aims drafted for the language and cultural learning as well as provides a means of how the teacher and student assess their intercultural competence through some criteria related to attitude, knowledge, and skill as parts of his definition of IC.

To reach further about the mentioned competencies above, this article, therefore, explains each of them. First, with the respect of the term linguistic competence defined by Tienson (1983), he stands to point that the idea of linguistic competence as a cognitive system yields knowledge in the mind of the subject, e.g., knowledge of such grammatical relations pertinent to certain stimuli, and it is also an essential contribution to the philosophical understanding of linguistics, and, generally, of cognitive psychology. In particular, it has been asserted that language grammar, grasps as a theory of linguistic competence, is an epitome, and that speakers understand the patterns of their language grammar correctly that are used. In addition to this, Byram's definition related to the concept of linguistic competence should be concerned seriously since he proposes it with the perspective of intercultural speaker, that is, the linguistic competence is outlined as a capacity in applying the knowledge of a language standard rule in producing and interpreting spoken and written language. Referring to their perspectives, the point that can be carried out is that the linguistic competence becomes very important element both in speaking and writing regarding the application of knowledge of such grammatical standard rules pertaining to the language utilization in the context of multiculturalism. Thus, this competence, for an EFL teacher, should be mastered at first in order to assist his or her students to have the capability in producing and employing the correct grammar language use effectively and appropriately in both spoken and written forms. 
Secondly, the sociolinguistic competence plays its role to help students to be able to live in multicultural situations. The reason why the students need to have this competence is that; according to Dewaele (2004), there have been some issues pertaining to the process of gaining and utilizing the range of the styles of speech or in increasing "stylistic variation". Furthermore, Brown (2000) figures out the sociolinguistic competence as to the student's understanding pertinent to the rules of sociolinguistic within the field of language and discourse. He includes the students' sensitivity to variety, register's choice, naturalism, and cultural references' knowledge and speech's figures. In more specific, Tarone \& Swain (1995) portray this competence as the members' capability in a kind of a speech community to deliver their speech in a proper way. Additionally, Byram argues that the competence of sociolinguistic is likely to be considered as the capacity to share the essential meaning uttered by a particular person which is usually taken for granted for the interlocutors, whether the interlocutors are the native speakers or not. Hence, from these views, they can be inferred that even though sociolinguistic competence is well known as the principal part of second language competency of the students, it leftovers a difficult concept to conceive, to define and to teach. The sociolinguistic competence assuredly let the learning of the sociocultural essential concept in and determines the proper behavior and language utilization of a certain community that is considered demanding and difficult to teach in a language classroom (Hinkel 2001). Thus, apart from its crucial role in assisting the students to be able to live in multicultural contexts, it is considered critical for the EFL teachers to master the sociolinguistic competence as well in order to overcome the difficulties attained by their students.

The discourse competence is also considered to be one of the important elements that should be possessed by the EFL teachers. The term discourse competence means that it is a component of communicative competence that is usually divided into four elements: (1) grammatical competence, (2) discourse competence, (3) socio-linguistic competence and (4) strategic competence (Canale \& Swain, 1980). Then, this argument can be related to Byram's definition of discourse competence that is the capability to utilize, uncover, and compromise several policies in producing and interpreting the texts of monologue or dialogue following the cultural styles of an interlocutor or particular purposes which are negotiated as intercultural texts. As stated previously, the four elements as well as the interpretation of Byram's definition related to the discourse competence, the EFL teachers should comprehend these elements in order to help the students to be able to implement the capability of such interpretations and productions of any intercultural texts and dialogues, as well as negotiate a particular issue with others in any cultural situations. This competence navigates the EFL teachers to direct their students to overcome some difficulties in rhetorical structures of a text so that they are likely to conduct the tasks given by their teachers in ease in any terms of intercultural texts.

Lastly, the intercultural competence (IC) is the fundamental element that the EFL teachers should master due to its elements, namely the attitude, knowledge, and skill. In this part, all these elements of IC, according to Byram (1997) become the most important parts of IC. In other words, in the perspective of intercultural competence, individuals possess the capacity to connect with other people from other countries with various cultural backgrounds and languages in order to draw on their knowledge pertinent to intercultural communication, their attitudes of enthusiasm towards otherness, as well as their skills and mastery in interpreting, relating and discovering, i.e. of conquering cultural dissimilarity and enjoying intercultural connection. Further, he also argues 
that there are three suggested categories of location to acquire the intercultural competence (IC) consisting of (1) the classroom, (2) the experiences outside the classroom which are pedagogically structured, and (3) the independent experiences. Yet, the emphasis of the IC elements is still solely to be mastered by the EFL teachers. The first element of IC, which is the attitude, is considered as the sense of curiosity, openness, as well as eagerness in suspending disbelief towards other cultures and belief towards ones' own (Byram, 1997). In this part, the EFL teachers are willing to seek out chances to mingle with otherness in an equal relationship; this should also be differentiated from attitudes of obtaining benefit from others, interesting in uncovering other world views on interpretation of both common and uncommon phenomena both in one's own as well as in other cultures and practices of cultures, willing to ask the presuppositions and values within the actions and products of cultures in one's own environment, being ready to be brave in experiencing the distinctive stages of adapting and interacting with other cultures, as well as being ready to engage with the agreement of verbal and non-verbal communication and interaction.

While for the knowledge, it contains the concept of social communities as well as the practices and products of social communities in the area of one's own and the interlocutor's country and of the common processes of individual and societal interactions (Byram, 1997). This element can be meant as the knowledge of acquiring the contemporary and historical association between one's own and the interlocutor's countries, the strategies in gaining connection with the interlocutors from another country which promote and encourage connection or help overcome some issues, the causes and practices of misconceptions between interlocutors' distinctive origins of culture, the national memory of one's own country and how the circumstances are interconnected to and perceived from the standpoint of interlocutor's country, the national memory of interlocutor's country and the viewpoint on it from one's own, the national interpretation of geographical space in one's own country and how these are recognized and apprehended from the point of view of other countries, the national identification of geographical space in the interlocutor's country and the outlook on them from one's own, the practices and institutions of socialization in one's own and interlocutor's country, social dissimilarities and the essential characters of social dissimilarities in one's own country and interlocutor's institutions, as well as perceptions and impression of the concept of social dissimilarities and the characters of social dissimilarities affecting the daily life of one's own and interlocutor's country as well as carrying out and impinging the relationships between them, and the activities of social interaction in the interlocutor's country.

Related to the skill, Byram (1997) divides it into two terms. The first term of skill is described as the skills of interpreting and relating in which it portrays the capability to elucidate a document or an event within a context of another culture as well as to describe and associate it to documents or events from one's own. The skills of interpreting and relating also comprises three abilities, namely, identifying ethnocentric point of views within an event or a document, in which according to Altan (2018), this ethnocentric mostly happens in the context of psychological boundaries between one owns cultures as well as the target cultures, and explaining their origins, identifying areas of misconceptions or dysfunction in the process of interaction and explaining them in accordance with every cultural system that presents, and mediating the interpretations of conflicting phenomena. Above all, the second term of skill is related to the skills of discovery and interaction in which it usually defines as the competence of acquiring new knowledge of cultural practices as well as the culture and competence of operating the knowledge, attitudes and skills 
with the constraints of communication and interaction in real-life situations acts as the principal consideration. Furthermore, the skills of discovery and interaction comprises the ability of eliciting the notion and significance of documents or phenomena in order to enhance the system of explanatory for applicative susceptible to other phenomena, identifying notable authorities within and across cultures and evoke their importance and connotations, identifying homogeneous and heterogeneous processes of interaction, verbal and non-verbal, and arranging an appropriate implementation of them in a particular circumstance, using a proper collaboration of knowledge, skills and attitudes to cooperate with interlocutors from dissimilar countries and cultures, making provision for the level of one's existing familiarity with the country and culture and the extent of differentiation between one's own and the others, identifying concurrent as well as former correlation between one's own and the other cultures and countries, identifying and taking an advantage of private and public institutions which encourage and promote contact with other cultures and countries, and employing the knowledge, skills and attitudes in a real life situation for the sake of mediation process between a foreign culture and interlocutors of one's own.

\section{CONCLUSION}

To sum up, the present article recommends that the Indonesian EFL teachers should comprehend the crucial elements of intercultural communicative competence, namely the linguistic, sociolinguistic, discourse, and intercultural competence. These elements are proposed by Byram (1997) in order to assist the language students to be able to live in multicultural situations and engage with the diverse people from any background of cultures. Besides, the Indonesian EFL teachers, in this case, should also implement the proposed element of intercultural communicative competence into their teaching and learning process. Once the Indonesian EFL teachers are successful in applying the elements effectively and appropriately, the students are likely able to live with multicultural people using the knowledge given by their teachers. Moreover, the Indonesian EFL teachers need to consider the appropriate location in order to acquire the intercultural competence by both the teachers and the students; those are the classroom, the experiences outside the classroom which are pedagogically structured, and also the independent experience. However, this article's emphasis is only to the elements of intercultural communicative competence as stated previously.

\section{REFERENCES}

Allen, R., Wood, B. (1978). Beyond Reading and Writing to Communication Competence. Communication Education (27), 286-292.

Altan, Z. M. (2018). Intercultural Sensitivity: A Study of Pre-service English Language Teachers. Journal of Intercultural Communication 46 (3), 1.

Brown H. Douglas. (2000). Teaching by Principles. Teaching by Principles An Interactive Approach to Language Pedagogy. https://doi.org/10.1016/S0346-251X(03)00040-X

Byram, M. (1997). Teaching and Assessing Intercultural Communicative. Clevedon: Multilingual Matters.

Canale, M., Swain, M. (1980). Theoretical Bases of Communicative Approaches to Second Language Teaching and Testing. Applied Linguistics 1 (1), 1-47. 
Intercultural Communicative Competence (ICC): What Should Indonesian EFL Teachers Have?

Chen, G., Starosta, W. (1996). Intercultural Communicative Competence: A Synthesis. Communication Yearbook (19), 353-383.

Chen, G., Starosta, W. (1999). A Review of the Concept of Intercultural Awareness. Human Communication (2), 27-54.

Cubukcu, F. (2013). Pre-Service English Teachers' Intercultural Sensitivity. International Journal of Human Sciences 10 (1), 832-843.

Delors, J. (1996). Learning, the Treasure within: Report to UNESCO of the International Commission on Education for the Twenty-First Century. Paris: UNESCO Pub.

Deardoff, D. (2006). Identification and Assessment of Intercultural Competence as a Student Outcome of Internalization. Journal of Studies in International Education 10 (3), 241-266.

Deardorff, D. (2009). Synthesising Conceptualisations of Intercultural Competence. In The SAGE Handbook of Intercultural Competence. CA: Sage Publications.

Dewaele, J. (2004). The Acquisition of Sociolinguistic Competence in French as a Foreign Language: An Overview. Journal of French Language Studies 14 (3), 301-319.

Fantini, A. (2000). A Central Concern: Developing Intercultural Competence. SIT Occasional Papers, 25-42.

Fantini, A. (2001). Exploring Intercultural Competence: A Construct Proposal. Paper, Presented as the $4^{\text {th }}$ Annual Conference of NCOLCTL, Brattleboro, Vermont.

Fantini, A. (2009). Assessing Intercultural Competence: Issues and Tools. In Deardoff, D. (eds.), The SAGE Handbook of Intercultural Competence (456-476). Thousand Oaks. CA: Sage.

Getter, H., Nowinski, J. (1981). A Free Response Test of Interpersonal Effectiveness. Journal of Personality Assessment (45), 301-308.

Hinkel, E. (2001). Building Awareness and Practical Skills for Cross-Cultural Communication in ESL/EFL. In M. Celce-Murcia (eds.), Teaching English as a Second or Foreign Language (443-458). Boston, MA: Heinle \& Heinle.

Insani, S. (2018). Language Learning: What Factors May Influence It. Journal of English Language Teaching and Linguistics) e-ISSN, 3(1), 2503-1848. Retrieved from www.jeltl.org

Jenkins, J. (2009). English as Lingua Franca: Interpretations and Attitudes. World Englishes 28 (2), 200-207.

Lázár, I., Huber-Kriegler, M., Lussier, D., Matei, G., Peck, C. (2007). Developing and Assessing Intercultural Communicative Competence: A Guide for Language Teachers and Teacher Educators. European Centre for Modern Languages. Strasbourg: Council of Europe..

Lee, L. (1979). Is Social Competence Independent of Cultural Context?. American Psychologist 34, 795-796.

Madya, S. (2013). Metodologi Pembelajaran Bahasa: Dari Era Prametode sampai Era Pascametode. Yogyakarta: UNY Press.

Rajic, V., Rajic, T. (2015). Assessment of Intercultural Competence of Vocational Teachers in Croatia. Andragoska Spoznanja 21(4), 37-51.

Samovar, L., Porter, R., McDaniel, E. (2012). Intercultural Communication: A Reader (13 ${ }^{\text {th }}$ Ed.). Boston: Wadsworth Cengage Learning.

Sercu, L. (2004). Assessing Intercultural Competence: A Framework for Systematic Test Development in Foreign Language Education and Beyond. Intercultural Education 15(1), 73-89.

JELTL (Journal of English Language Teaching and Linguistics), 4(1), 2019 
Mas Muhammad Idris \& Agus Widyantoro

Sercu, L. (2005). Teaching Foreign Languages in an Intercultural World. In Byram, M., Phipps, A (eds.), Foreign Language Teachers and Intercultural Competence, 1-18. Buffalo: Multilingual Matters, Ltd.

Sercu, L. (2010). Assessing Intercultural Competence: More Questions than Answers. In Paran, A., Sercu, L (eds.), Testing the Untestable in Language Education, 17-34. Clevedon: Multilingual Matters.

Spitzberg, B., Cupach, W. (1984). Interpersonal Communication Competence. Beverly Hills, CA: Sage.

Sudhoff, J. (2010). CLILC AND Intercultural Communicative Competence: Foundations and Approaches towards a Fusion. International CLIL Research Journal 1(3), 30-37.

Traone, E., Swain, M. (1995). A Sociolinguistic Perspective on L2 Use in Immersion Classrooms. The Modern Language Journal 79(2), 166-178.

Tienson, J. (1983). "Linguistic Competence": Transactions of the Nebraska Academy of Sciences and Affiliated Societies. 259. http://digitalcommons.unl.edu/tnas/259

Trenholm, S., Rose, T. (1981). The Compliant Communicator: Teacher Perceptions of Classroom Behavior. Western Journal of Speech Communication 45, 13-26.

UNESCO. (2006). Guidelines on International Education. Paris: UNESCO Headquarters.

Weinstein, E. (1969). The Development of Interpersonal Competence. In Goslin, D (eds.), Handbook of Socialization Theory and Research, 753-775. Chicago: Rand McNally.

White, G. (1980). Conceptual Universals in Interpersonal Language. American Anthropologist $82,759-781$. 